4. Gilbert B., McDougall P., Audretsch D. New venture growth: A review and extension.//Journal of Management. - 2006. - 32, 926-950.

5. Baum R., Locke E., Smith K. A multidimensional model of venture growth.//Academy of management journal. - 2001. - 44, 926-950.

6. Davidsson P., Wiklund J. Conceptual and empirical challenges in the study of firm growth. In: D. Sexton, H. Landstrom (Eds.). The Blackwell handbook of entrepreneurship. - Oxford, MA: Blackwell, 2000. - P. 179-199.

7. КуАина М.В. Теория стоимости компании. - М.: ИзА-во Московского университета, 2013.

8. Greiner L. Evolution and revolution as organizational growth.//Harvard business review. - July-August 1972,37-48.

9. Garnsey E., Stam E., Hefferman P. New firm growth: exploring processes and paths.//Industry and innovation. $-2006 .-13,8-17$.

Leonova Julia Gennadievna,

Plekhanov Russian University of Economics, associate professor, Department of Trade policy

E-mail: julialeon@inbox.ru

\title{
Peculiarities of performance assessment of a trade organization in a competitive market
}

\begin{abstract}
The trade sector is characterized by a high level of competition. In this connection assessment of the economic efficiency of trade organizations is a prerequisite of its adaptation to the competitive conditions of market environment. The article is concerned with the main methodological approaches to the integrated study of the efficiency of a trade organization in the commodity market.

Keywords: methodologies for assessing efficiency, complex assessment of efficiency, efficiency of a trade organization, assessment of customers satisfaction.

The integration of trade organizations in the marketdriven economy is directly related to their performance, since insufficiently effective activity unavoidably leads to a loss of competitive position on the commodity market. Informed managerial decisions making requires an information foundation, so trade organizations should pay considerable attention to the improvement of the analytical work. Development of theoretical and methodological issues related to assessment, analysis and planning of efficiency is a key prerequisite for creation of a coherent and effective economic mechanism of a trade organization and its adaptation to the competitive conditions of market environment.

In the special economic literature, there are described many methodologies for assessing efficiency, as well as ideas of scientific understanding of its quality content as an economic category [1].

Efficiency category is used as a criterion for generalizing the expediency and rationality of economical and organizational solutions of trade organizations. Every trade organization is a complex economic system, consisting of a set of elements, among which there are multiple links. Therefore, it is practically impossible to measure and express the efficiency of a trade organization in

terms of a single indicator. Along with this, the efficiency is a complex category determined by many factors and has various manifestations.

There are three main methodological approaches to the integrated study of the efficiency of a trade organization.

The first approach is the most common in the economic literature. According to this approach, assessment of a trade organization performance is the same as assessment of its economic efficiency and limited by calculation of the relevant economic and financial indicators characterizing the rational use of resources, cost-effectiveness, and economic efficiency of the operation. This approach can be considered as quite reasonable, given that the indicators of economic efficiency usually play a primary role in conducting a complex assessment of business activity efficiency of a trade organization.

However, due to primarily financial focus, these indicators insufficiently direct activity of trade entities towards a customer, and thus do not provide an objective assessment of the economic efficiency of trade organizations in terms of their competitiveness. In addition, economic efficiency is just a component of the overall trading entity performance.
\end{abstract}


That's why, the second approach implies building a system of indicators that comprehensively reflect different aspects of the efficiency of trading activities.

At the same time in the overall system of a trading company performance, depending on the aspect (direction) of the study there can be singled out four large groups (units) of analytical indicators:

- financial and economic indicators (efficiency indicators of use of material, labor, and financial resources, cost effectiveness, performance indicators);

- organizational indicators (Indicators showing the organization of economic relations with suppliers and customers; indicators of storage operations organization; indicators of work organization in the sales area);

- logistics indicators (indicators of quality of logistics customer service, inventory management indicators, transportation indicators);

- competitiveness indicators (indicators of goods competitiveness, indicators of service competitiveness; competitiveness indicators of a trade organization in general).

The exact composition of the indicators included in each of these groups is quite traditional and widely reported in the literature on the problems of studying the economics of trade organizations, commerce, logistics, and marketing.

Taken together, these figures fully reflect the operating efficiency of trade organizations. The composition and relevance of indicators in each of these groups will be a little different for enterprises of various sub-sectors of trade (wholesale, retail). For example, the content of most of organizational indicators will be different. In particular, due to the fact that a retail customer is the population - the end user, there is no sense to calculate indicators of economic relations organization with buyers for retailers. Also, because of the specific activities, for retail organizations, in opposite to wholesale ones, as a part of organizational indicators, the indicators of the storage operations organization will be of greatest relevance, instead of the indicators of work organization in the sales area. The composition of certain logistic efficiency indicators will be different for retail and wholesale trades.

Economic success of trade organization in today's competitive commodity market is largely dependent on how much its sold goods and provided services satisfy demands of buyers (customers). Thus, the third approach of performance assessment of trade organizations is a customer-oriented, which implies taking into account the degree of customes satisfaction when calculating traditional indicators of economic efficiency [2].
Focus of trade organizations on customers demands makes it necessary to pay greater attention to the problem of assessing customers satisfaction by their inventory and service offerings. The system of assessment of a customer satisfaction serves as a key factor in the quality of service of a trade organization.

Buyers preferences - one of the important aspects of business activity of a trade organization, which is neither taken into account, nor statistically observed, though playing a key role in its dynamic. If a trade organization is able to bring the entire set of activities under this criterion, which is customer satisfaction, it will be provided with a sufficiently high level of competitiveness on the market.

Therefore, to maintain and develop its market position a trade organization needs to find out the needs of customers and to carry out regular monitoring of their level of satisfaction. The level of satisfaction of customers needs, in fact, characterizes the level of service of trade organizations. At the same time the level of service is determined by quality (broadly speaking), which is applied to a trade organization and consists of two components: quality of easy-to-sell goods and the quality of services rendered.

Currently, the term of "service level" is used almost in any trade organization, but as a rule, it's not defined in clear terms, agreed with all intercompany services and departments, which would also take into account customers engagement [3].

A complex assessment of the level of customers satisfaction allows a trade organization to determine a competitive level of service, equally adequate to the requirements of a competitive product market.

Procedure for assessment of the level of meeting customers' demands by a trading organization includes a number of stages: selection of parameters that form the concept of "customer satisfaction" in respect of easyto-sell goods and services rendered (including quality and range of goods and commercial services, reliability of goods supply, speed of trading service, level and flexibility of the price etc. depending on the specifics of a trade organization's activity); formalization of these parameters in the form of private estimates, determination of the significance coefficients of each particular indicator; calculation of the average, actual (for this trade organization), and competitive values of parameters (by comparing the actual and the average values and selecting the best); determination of the actual and competitive values of integral indicator of the level of meeting customers' demands by a trade organization.

The actual value of the integral index of the level of meeting customers' demands for a trade organization is 
that assessment of the level customers satisfaction is made at a fixed time. Bringing together performance in a single parameter (i. e. the definition of the arithmetic mean between the weighted average values of the partial figures) gives an overview of the service system on a trade organization scale. This aggregated assessment provides an overall overview of performance and identify potential problems in the area of service. Supported by detailed analysis of individual indicators of customer satisfaction allows you to discover the specific problems in the background of the general situation.

The economic sense of the competitive value of the integral index is that it reflects the level of satisfaction of customers by a trade organization when achieving the parameters of a single average level of service, and maintaining the other parameters of the service with already achieved level, climbing above the market average.

The calculation of the integral index, based on a detailed analysis of indicators of the level of customer satisfaction allows to identify key areas for improving sales strategy of a trade organization. The market average standards of service provide a trade organization with guidelines for application of efforts in improving the realizable policies, because they reflect not just a hypothetical market average "ideal", but the real situation in a relatively narrow segment of the market.
Thus, the competitive value of the integral indicator of the level of meeting buyers demands can act as a following strategy of a trade organization in the field of improvement of the system of customer service. Compliance with the terms of service at a level no lower than the market average in all key parameters will contribute to strengthening the competitive position of a trade organization in particular segment of the market, reducing the risk of being crowded out by the competitors. On the other hand, if you already have exceeded the average values on a number of parameters, when bringing into compliance the other elements of the service, it will positively affect the competitive potential of a trade organization.

In the future, you can define additional economic efficiency, which a trade organization would have when achieving the competitive value of the integral indicator of the level of meeting customers' demands. The basis for this can be the difference between the potential (when achieving the competitive level of customers satisfaction) and the actual size of margins costs.

Thus, the practical application of customer-oriented approach to the assessment of the economic efficiency of trade organizations may become a prerequisite of either the strengthening of their competitive position in the commodity market, or the positive dynamics of indicators of economic activity.

\section{References:}

1. Maslova A.E., Timyasheva E. T., Nikishin A.F. Factors that form an attractive image of trade organizations.//Austrian Journal of Humanities and Social Sciences. - 2015. - № 7-8. - P. 146-147.

2. Tyunik O. R., Nikishin A.F., Pankina T.V. Improvement of goods flow in current economic environment.//Proceedings of the $7^{\text {th }}$ International Conference on Economic Sciences. - «East West» Association for Advanced Studies and Higher Education GmbH. Vienna, 2015. - P. 7-10.

3. Ivanov G., Mayorova E. Intangible assets and competitive advantage in retail: case study from Russia.//Asian Social Science. - 2015. - T. 11. - № 12. - P. 38-45.

Nikishin Alexander Fedorovich,

Pankina Tatiana Viktorovna,

Zvereva Anna Olegovna, Plekhanov Russian University of Economics, associate professors, Department of Trade policy

E-mail:ktdn@yandex.ru

\section{Transport accessibility of trading organizations}

Abstract: In the modern world the role of transport accessibility is ever increasing. In that regard not pedestrians' but transport accessibility of trade organizations plays ever larger role. An article is devoted to consideration of a factor of transport accessibility of trade organizations.

Keywords: Trade, retail, transport accessibility, express trains. 